\title{
PENGARUH UKURAN PEMERINTAH DAERAH, RASIO KEMANDIRIAN DAERAH, RASIO PEMBIAYAAN HUTANG, DAN BELANJA DAERAH TERHADAP PELAPORAN KEUANGAN PEMERINTAH DAERAH
}

Oleh :

Christina, SE, M.Si

\section{Fakultas Ekonomi Program Studi Akuntansi Universitas Satya Negara Indonesia}

\begin{abstract}
ABSTRAK
Tujuan penelitian adalah untuk mengetahui pengaruh ukuran pemerintah daerah, rasio kemandirian daerah, rasio pembiayaan hutang, dan belanja daerah secara parsial dan simultan terhadap pelaporan keuangan pemerintah daerah. Desain penelitian yang digunakan adalah desain kausal. Populasi penelitian ini adalah seluruh pemerintahan kabupaten/kota di Indonesia sebanyak 514 tahun 2015. Sampel dipilih dengan menggunakan metode purposive sampling berjumlah 80 kabupaten/kota di Indonesia. Data diolah menggunakan uji regresi logistik. Hasil penelitian ini membuktikan bahwa Ukuran Pemerintah Daerah, Rasio Kemandirian Daerah, Rasio Pembiayaan Hutang, dan Belanja Daerah secara simultan berpengaruh signifikan terhadap Pelaporan Keuangan Pemerintah Daerah. Secara parsial, Ukuran Pemerintah Daerah, Rasio Kemandirian Daerah dan Rasio Pembiayaan Hutang berpengaruh terhadap Pelaporan Keuangan Pemerintah Daerah, sedangkan Belanja Daerah berpengaruh tidak signifikan terhadap Pelaporan Keuangan Pemerintah Daerah.Kemampuan prediksi dari keempat variabel tersebut terhadap Pelaporan Keuangan Pemerintah Daerah sebesar $48.40 \%$ sedangkan sisanya sebesar $51.60 \%$ dipengaruhi oleh faktor lain yang tidak dimasukkan ke dalam model penelitian.

Kata Kunci : Pelaporan Keuangan Pemerintah Daerah, Ukuran Pemerintah Daerah, Rasio Kemandirian Daerah, Rasio Pembiayaan Hutang, dan Belanja Daerah.
\end{abstract}




\section{PENDAHULUAN}

Perubahan yang terjadi pada pengelolaan keuangan daerah merupakan salah satu dampak diterapkannya otonomi daerah. Untuk melaksanakan otonomi daerah, pemerintah pusat menerbitkan UU Nomor 32 Tahun 2004 tentang Pemerintahan Daerah. Selain itu, pemerintah pusat juga menerbitkan beberapa peraturan pemerintah (PP) menyangkut pengelolaan keuangan daerah diantaranya, PP Nomor 58 Tahun 2005 tentang Pengelolaan Keuangan Daerah dan Permendagri Nomor 13 Tahun 2006 tentang Pedoman Pengelolaan Keuangan Daerah. Pemerintah daerah sebagai pelaksana pengelolaan keuangan daerah diharuskan untuk menyajikan Laporan Keuangan Pemerintah Daerah sebagai bentuk pertanggungjawaban.

Salah satu bentuk transparansi yang dapat ditempuh pemerintah daerah ialah dengan pelaporan keuangan secara sukarela di internet sehingga seluruh pihak yang berkepentingan memiliki kesempatan untuk memperoleh informasi yang ada di lingkungan pemerintahan. Pelaporan keuangan secara sukarela di internet dinilai efisien dan efektif meningkatkan transparansi dan akuntabilitas. Pada saat ini, terdapat faktor heterogenitas diantara pemerintah daerah di Indonesia dimana informasi akuntansi di internet diungkapkan secara bervariasi mulai dari yang paling sedikit hingga yang paling lengkap.

Untuk mendukung terciptanya transparansi dan akuntabilitas publik serta kepuasan pelayanan terhadap masyarakat, dengan adanya otonomi daerah pemerintah daerah memiliki otoritas untuk berinovasi memberikan pelayanan yang terbaik bagi publik. Kepala daerah dapat menggunakan internet untuk mengungkapkan pertanggungjawaban secara sukarela sebagai upaya konkrit mewujudkan akuntabilitas.

Ukuran pemerintahan daerah dapat dilihat dari aset yang dimiliki pemerintahan daerah tersebut. Semakin besar aset menandakan jumlah transfer kekayaan yang dikelola oleh perangkat pemerintahan daerah semakin besar pula. Mengingat kebutuhan untuk pengungkapan yang lebih besar oleh ukuran pemerintahan daerah yang besar, diharapkan pemerintahan daerah tersebut akan cenderung menggunakan berbagai metode pengungkapan.

Rasio kemandirian daerah menunjukkan kemampuan daerah dari sumber-sumber pendapatan asli daerah untuk membiayai operasional daerah dalam mewujudkan pembangunan daerah dan pelayanan kepada masyarakat (Rora, 2010). Pemerintah daerah yang memiliki kualitas manajemen yang baik cenderung untuk mengungkapkan informasi yang banyak menggunakan sistem yang dapat meningkatkan kualitas dari pemerintah daerah tersebut seperti dengan menyediakan informasi keuangan pada situs resminya.

Dengan melakukan pembiayaan terhadap pengeluaran-pengeluaran pemerintah akan memberikan dampak pada kemampuan pemerintah dalam memberikan pelayanan dan program-program terpadu bagi masyarakat dimasa yang akan datang, namun besaran hutang tidak boleh melebihi jumlah dari modal yang dimiliki (Styles dan Tennyson, 2007).

Seluruh pendapatan daerah yang diperoleh baik dari daerahnya sendiri maupun bantuan dari pemerintah pusat akan digunakan untuk membiayai seluruh pengeluaran daerah itu. Menurut PP Nomor 58 Tahun 2005 tentang Pengelolaan Keuangan Daerah : Pasal 20, belanja daerah meliputi semua pengeluaran dari rekening kas umum daerah yang mengurangi ekuitas dana lancar, yang merupakan kewajiban daerah dalam satu tahun anggaran yang tidak akan diperoleh pembayarannya kembali oleh daerah. Pada Pasal 26, belanja daerah 
dipergunakan dalam rangka pelaksanaan urusan pemerintahan yang menjadi kewenangan provinsi atau kabupaten/kota yang terdiri dari urusan wajib dan urusan pilihan yang ditetapkan dengan ketentuan perundang-undangan.

Berdasarkan uraian tersebut, maka peneliti tertarik untuk melakukan penelitian dengan judul :"Pengaruh ukuran pemerintah daerah, rasio kemandirian daerah, rasio pembiayaan hutang, dan belanja daerah terhadap pelaporan keuangan pemerintah daerah".

\section{Perumusan Masalah}

Apakah ukuran pemerintah daerah, rasio kemandirian daerah, rasio pembiayaan hutang, dan belanja daerah berpengaruh secara parsial dan simultan terhadap pelaporan keuangan pemerintah daerah?

\section{Tujuan penelitian}

Untuk mengetahui pengaruh ukuran pemerintah daerah, rasio kemandirian daerah, rasio pembiayaan hutang, dan belanja daerah secara parsial dan simultan terhadap pelaporan keuangan pemerintah daerah.

\section{ManfaatPenelitian}

1. Bagi akademisi, menjadi bahan literatur untuk pengembangan penelitian selanjutnya tentang sektor publik.

2. Bagi peneliti, dapat memberikan kontribusi keilmuandan mengembangkan wawasan mengenaipelaporan keuangan pemda.

3. Bagi pemerintah daerah,diharapkanpemda mulai memperhatikan perkembangan dan kegunaan dari internet serta memotivasipemda lain untuk mengembangkan situs resminya dalam penyampaian informasi pelaporan keuangannya.

4. Bagi regulator, sebagai bahan masukan mengenai pentingnya pelaporan keuangan di dalam media internet untuk meningkatkan akuntabilitas dan transparansi pengelolaan keuangan pemerintah daerah kepada masyarakat.

5. Bagi publik, masyarakat dapat mengetahui pemda mana saja yang memberikan informasi keuangan.

\section{LANDASAN TEORI \\ Keuangan Pemerintah Daerah}

Di Indonesia, reformasi pengelolaan keuangan dimulai dengan dikeluarkannya tiga buah paket undang-undang pada tahun 2003 dan 2004. UU Nomor 17 Tahun 2003 tentang Keuangan Negara, UU Nomor 1 Tahun 2004 tentang Perbendaharaan Negara dan UU Nomor 15 Tahun 2004 tentang Pemeriksaan Pengelolaan dan Tanggung Jawab Keuangan Negara merupakan dasar dari pelaksanaan reformasi pengelolaan keuangan di Indonesia. Reformasi pengelolaan keuangan dimulai dari proses perencanaan dan penganggaran, pelaksanaan anggaran, hingga pertanggungjawaban keuangan dan audit.

Keuangan daerah menurut PP No. 58 tahun 2005 adalah semua hak dan kewajiban daerah dalam rangka penyelenggaraan pemerintahan daerah yang dapat dinilai dengan uang termasuk didalamnya segala bentuk kekayaan yang berhubungan dengan hak dan kewajiban daerah tersebut.Anggaran Pendapatan dan Belanja Daerah (APBD) menurut PP No. 58 tahun 2005 adalah rencana keuangan tahunan pemerintahan daerah yang dibahas dan disetujui bersama oleh pemerintah daerah dan DPRD. Dalam APBD tergambar semua hak dan kewajiban daerah dalam rangka penyelenggaraan Pemerintah Daerah yang dapat dinilai 
dengan uang termasuk di dalamnya segala bentuk kekayaan yang berhubungan dengan hak dan kewajiban daerah tersebut dalam kurun satu tahun.

\section{Pelaporan Keuangan}

Pelaporan keuangan merupakan suatu bentuk pengungkapan informasi keuangan.Pengungkapan berarti memberikan data yang bermanfaat kepada pihak yang memerlukan.Tujuan pelaporan keuangan diupayakan mempunyai cakupan yang luas agar memenuhi berbagai kebutuhan para pemakai dan melayani kepentingan umum dari berbagai pemakai yang potensial, bukan hanya untuk kebutuhan khusus kelompok tertentu saja (Kieso dkk, 2007).

Pelaporan keuangan daerah adalah struktur dan proses akuntansi yang menggambarkan bagaimana informasi tentang keuangan pemerintah daerah disediakan dan dilaporkan untuk mencapai tujuan ekonomi dan sosial Negara. Unsur-unsur didalam informasi keuangan daerah berdasarkan PP No. 56 tahun 2005 yang dibahas dalam penelitian ini adalah LKPD dan APBD. APBD terdiri atas :

1. Anggaran Pendapatan, diantaranya :

a. Pendapatan Asli Daerah : Pajak daerah, Retribusi daerah, dan Penerimaan lain-lain.

b. Dana Perimbangan : Dana bagi hasil, Dana Alokasi Umum (DAU) dan Dana Alokasi Khusus (DAK).

c. Lain-lain pendapatan yang sah.

2. Anggaran belanja, diklasifikasikan menurut organisasi, fungsi, program, kegiatan dan jenis belanja. Anggaran belanja digunakan untuk membiayai penyelenggaraan tugas pemerintah daerah.

3. Pembiayaan, terdiri atas penerimaan pembiayaan dan pengeluaran pembiayaan.

Peraturan mengenai APBD ditentukan dalam Undang-Undang Republik Indonesia Nomor 17 Tahun 2003 tentang Keuangan Negara, Peraturan Pemerintah Republik Indonesia Nomor 58 Tahun 2005, dan Permendagri Nomor 59 Tahun 2007. Laporan pertanggungjawaban pelaksanaan APBD disampaikan setidaknya terdiri dari Laporan Realisasi Anggaran, Neraca, Laporan Arus Kas dan Catatan atas Laporan Keuangan. Penyampaian Laporan Keuangan Pemerintah Daerah (LKPD) oleh pemerintah daerah ditetapkan dalam Undang-Undang Republik Indonesia Nomor 17 tahun 2003 Pasal 31 dan UU Nomor 1 tahun 2004. UU Nomor 1 tahun 2004 menyatakan bahwa penyampaian LKPD oleh Gubernur/Bupati/Walikota kepada Badan Pemeriksa Keuangan (BPK) paling lambat 6 (enam) bulan setelah tahun anggaran berakhir.

\section{Laporan Keuangan Pemerintah Daerah}

Sesuai Pernyataan Nomor 1 Standar Akuntansi Pemerintahan tentang penyajian laporan keuangan, laporan keuangan merupakan laporan yang terstruktur mengenai posisi keuangan dan transaksi-transaksi yang dilakukan oleh suatu entitas pelaporan.Tujuan umum laporan keuangan adalah menyajikan informasi mengenai posisi keuangan, realisasi anggaran, arus kas, dan kinerja keuangan suatu entitas pelaporan yang bermanfaat bagi para pengguna dalam membuat dan mengevaluasi keputusan mengenai alokasi sumber daya. 
Komponen-komponen yang terdapat dalam suatu set laporan keuangan pokok adalah:

a) Laporan Realisasi Anggaran

Laporan realisasi anggaran menyajikan ikhtisar sumber, alokasi, dan pemakaian sumber daya ekonomi yang dikelola oleh pemerintah daerah, yang menggambarkan perbandingan antara anggaran dan reaisasinya dalam satu periode pelaporan.

b) Neraca

Neraca menggambarkan posisi keuangan pemerintahan daerah mengenai aset, kewajiban, dan ekuitas dana pada tanggal tertentu.

c) Laporan Arus Kas

Laporan arus kas menyajikan informasi mengenai sumber, penggunaan, perubahan kas dan setara kas selama satu periode akuntansi, dan saldo kas dan setara kas pada tanggal pelaporan.

d) Catatan atas Laporan Keuangan

Catatan atas laporan keuangan meliputi penjelasan naratif atau rincian dari angka yang tertera dalam laporan realisasi anggaran, neraca, dan laporan arus kas.

\section{Sistem Informasi Keuangan Daerah}

Sistem Informasi Keuangan Daerah (SIKD) adalah aplikasi terpadu yang dipergunakan sebagai alat bantu pemerintah daerah yang digunakan meningkatkan efektifitas implementasi dari berbagai regulasi bidang pengelolaan keuangan daerah yang berdasarkan pada asas efisiensi, ekonomis, efektif, transparan, akuntabel dan auditabel. Selanjutnya, UU nomor 33 Tahun 2004 tentang perimbangan keuangan antara pemerintah pusat dengan daerah pasal 103 yang menyatakan bahwa informasi yang dimuat dalam sistem informasi keuangan daerah adalah datayang terbuka yang dapat diketahui, diakses, dan diperoleh masyarakat. Ini artinya bahwa pemerintah daerah dituntut membuka akses kepada masyarakat secara luas atas informasi keuangan yang dihasilkan pemda, misalnya dengan mempublikasikan informasi keuangan daerah melalui surat kabar, internet, atau lainnya.

Untuk menindaklanjuti pelaksanaan dari UU Nomor 33 Tahun 2004 maka Pemerintah mengeluarkan PP Nomor 56 Tahun 2005 tentang Pelaksanaan Sistem Informasi Keuangan Daerah. Informasi Keuangan Daerah yang tertuang dalam PP Nomor 56 Tahun 2005 Pasal 4 pada pelaksanaanya disampaikan oleh daerah kepada pemerintah mencakup :

1. APBD dan realisasi APBD provinsi, kota dan kabupaten

2. Neraca daerah

3. Laporan arus kas

4. Catatan atas laporan keuangan daerah

5. Dana dekonsentrasi dan dana tugas pembantuan

6. Laporan keuangan perubahan daerah, dan

7. Data yang berkaitan dengan kebutuhan fiskal dan kapasitas fiskal daerah.

Informasi keuangan tersebut harus disampaikan kepada Menteri Keuangan dan Menteri Dalam Negeri. Penyampaian informasi keuangan daerah dilakukan secara berkala melalui dokumen tertulis dan media lainnya. Pemerintah daerah juga berkewajiban untuk menyajikan informasi keuangan daerah secara terbuka kepada masyarakat. Pemerintah daerah dapat menggunakan situs resminya sebagai media publikasi informasi keuangan. 


\section{Struktur Pemerintahan Indonesia}

Struktur pemerintahan Indonesia terdiri dari pemerintah pusat dan daerah. Pemerintah daerah terdiri dari pemerintah provinsi, pemerintah kota, dan pemerintah kabupaten. UU No.32 Tahun 2004 mengatur tentang pemerintah daerah dan UUNo.33 Tahun 2004 mengatur tentang perimbangan keuangan antara pemerintah pusat dan pemerintah daerah untuk mengelola sumber daya yang dimilikinya. Pemerintah daerah memiliki kewenangan sekaligus tanggung jawab atas sumber daya yang berasal dari dana-dana masyarakat yang dikelola olehnya. Undang-Undang Nomor 32 Tahun 2004 Pasal 1 bahwa pemerintah daerah meliputi Gubernur, Walikota atau Bupati dan perangkat daerah sebagai unsur penyelenggaraan pemerintah daerah.

\section{Manfaat Pelaporan Keuangan}

Suatu cara yang mungkin paling nyaman dan cost effective bagi pihak pemerintahan untuk menyebarkan informasi di zaman sekarang adalah menggunakan internet. Peraturan menggunakan internet untuk menyebarkan laporan tahunan pemerintahan kepada masyarakat sudah menjadi perhatian Governance Finance Officers Association (GFOA) di Amerika Serikat. GFOA meyakini banyak manfaat dari publikasi dengan menggunakan internet, diantaranya :

1. Meningkatkan kepedulian terhadap dokumen.

2. Meningkatkan pemakaian oleh stakeholders.

3. Merupakan alat analisis yang lebih mudah untuk diaplikasikan.

4. Mencegah kelebihan pengungkapan dan menghemat biaya publikasi.

Ukuran pemda mempengaruhi pelaporan keuangan di internet secara sukarela karena semakin besar ukuran pemda menandakan jumlah dan transfer kekayaan yang dikelola oleh perangkat pemerintahan daerah semakin besar pula sehingga biaya pemantauan tinggi.

Rasio kemandiriandaerah menunjukkan kemampuan daerah dari sumber-sumber pendapatan asli daerah untuk membiayai pengeluaran operasional daerah dalam mewujudkan pembangunan daerah dan pelayanan kepada masyarakat. Besarnya kemampuan daerah dalam membiayai sendiri kegiatan pada daerah menunjukkan kinerja pemerintahnya yang baik. Kinerja pemerintah yang baik akan menunjukkan kualitas dari manajemen pemerintahan yang baik. Pemda yang memiliki kualitas manajemen yang baik cenderung untuk mengungkapkan informasi yang lebih banyak dan menggunakan sistem yang dapat meningkatkan kualitas dari pemda tersebut.

Pembiayaan terhadap pengeluaran-pengeluaran pemerintah akan memberikan dampak pada kemampuan pemerintah dalam memberikan pelayanan dan program-program terpadu bagi masyarakat dimasa yang akan datang. Namunbesaran dari hutang tidak boleh melebihi jumlah dari modal yang dimiliki. Hubungan keagenan antara otoritas daerah dan pemerintah pusat (kreditur) memberikan dampak pada besarnya tingkat pengungkapan. Kreditur cenderung memonitor para debiturnya dalam pengelolaan keuangan. Pengungkapan informasi keuangan melalui media tradisional maupun internet dapat memfasilitasi kreditur untuk mengawasi kinerja pemerintah (Gore, 2004).

Seluruh pendapatan daerah yang diperoleh baik dari daerahnya sendiri maupun bantuan dari pemerintah pusat akan digunakan untuk membiayai seluruh pengeluaran daerah itu. Pendapatan daerah itu bisa berupa (PAD), dana perimbangan dan lain-lain pendapatan daerah yang sah. Menurut UU No. 32 Tahun 2004 tentang Pemerintah Daerah, belanja daerah 
adalah semua kewajiban daerah yang diakui sebagai pengurang nilai kekayaan bersih dalam periode anggaran yang bersangkutan.

Daerah yang populasinya banyak dan memiliki beragam latar belakang sosial, maka permasalahan pemdanya semakin kompleks.Semakin kompleks permasalahan di suatu daerah maka semakin besar pula tanggung jawab pemda untuk dapat memberikan pelayanan yang maksimal bagi warganya.Internet merupakan media yang paling efisien dalam memberikan pelayanan penduduk di suatu daerah.Karena internet dapat menjangkau populasi penduduk yang lebih besar dalam memberikan pelayanan bagi pemerintah daerah.

\section{Kerangka Konsep}

\begin{tabular}{|l|l|}
\hline Ukuran Pemda $\left(\mathrm{X}_{1}\right)$ & \\
\hline Rasio Kemandirian Daerah $\left(\mathrm{X}_{2}\right)$ \\
\hline Rasio Pembiayaan Hutang $\left(\mathrm{X}_{3}\right)$ \\
\hline Belanja Daerah $\left(\mathrm{X}_{4}\right)$
\end{tabular}

\section{METODE PENELITIAN}

\section{Jenis Penelitian}

Penelitian ini termasuk penelitian deskriptif kuantitatif yang menekankan pada hubungan kausal (causal effect). Penelitian ini adalah untuk menguji pengaruh ukuran pemerintah daerah, rasio kemandirian daerah, rasio pembiayaan hutang, belanja daerah, dan tipe pemerintahan daerah terhadap pelaporan keuangan pemerintah daerah.

\section{Hipotesis}

Ukuran pemerintah daerah, rasio kemandirian daerah, rasio pembiayaan hutang, dan belanja daerahberpengaruh signifikan baik secara parsial maupun simultan terhadap pelaporan keuangan pemerintah daerah.

\section{Populasi dan Sampel Penelitian}

Populasi penelitian ini adalah seluruh pemerintahan kabupaten/kota di Indonesia berjumlah 514, yang terdiri dari pemerintahan kota berjumlah 98 dan pemerintahan kabupaten berjumlah 416. Sampel yang digunakan dalam penelitian ini adalah 80 kabupaten/kota di Indonesia pada tahun 2015. Pengambilan sampel dilakukan dengan menggunakan metode purposive sampling. berikut:

Sampel dipilih dengan metode purposive sampling, dengan kriteria sampel sebagai

(1) Menyediakan informasi Laporan Keuangan Pemerintah Daerah (LKPD) tahun 2015 kabupaten/kota yang telah diaudit oleh BPK,

(2) Hasil pemeriksaan LKPD oleh BPK menunjukkan opini WTP dan WDP,

(3) Menyediakan situs resmi pemerintah daerah kabupaten/kota di Indonesia dan masih aktif,

(4) Pemerintah daerah yang mempublikasikan informasi keuangan yang lengkap pada situs resmi pemerintah daerah kabupaten/kota di Indonesia. 


\section{Ringkasan Pemilihan Sampel}

\begin{tabular}{ll}
\hline Keterangan & Kriteria \\
\hline $\begin{array}{l}\text { Laporan Keuangan Pemerintah Daerah (LKPD) Tahun 2015 di } \\
\text { Indonesia yang telah diaudit oleh BPK }\end{array}$ & 514 \\
\hline $\begin{array}{l}\text { LKPD yang mendapat opini tidak wajar (TW) dan Tidak memberikan } \\
\text { Pendapat (TMP) }\end{array}$ & -23 \\
\hline Pemerintah daerah yang tidak memiliki situs resmi dan offline & -178 \\
\hline $\begin{array}{l}\text { Pemerintah daerah kab/kota yang tidak mempublikasikan informasi } \\
\text { keuangan }\end{array}$ & -233 \\
\hline Sampel Terkumpul & $\mathbf{8 0}$ \\
\hline
\end{tabular}

\section{Metode Pengumpulan Data}

Data yang dipergunakan pada penelitian ini adalah data sekunder. Data-data tersebut adalah berupa LKPD, APBD, dan laporan hasil pemeriksaan BPK tahun 2015 semester I

\begin{tabular}{|c|c|c|c|}
\hline Variabel & Definisi Operasional & Parameter & $\begin{array}{l}\text { Skala } \\
\text { Ukur }\end{array}$ \\
\hline $\begin{array}{l}\text { PelaporanKeuangan } \\
\text { Pemerintah Daerah } \\
\text { (Y) }\end{array}$ & $\begin{array}{lr}\text { Pelaporan } & \text { Keuangan } \\
\text { adalah } & \text { pemberian } \\
\text { informasi } & \text { keuangan } \\
\text { melalui media } & \text { internet } \\
\text { yang dilakukan } & \text { oleh } \\
\text { pemerintah } & \text { daerah } \\
\text { sekalipun } & \text { tidak } \\
\text { diwajibkan dalam } & \text { suatu } \\
\text { peraturan. } & \end{array}$ & \begin{tabular}{lr}
\multicolumn{3}{l}{ Variabel dummy pelaporan } \\
keuangan pemda di \\
internet (nilai 1 untuk \\
pemda & yang \\
mempublikasikan laporan \\
keuangan dannilai & 0 untuk \\
pemda yang tidak \\
mempublikasikan laporan \\
keuangan)
\end{tabular} & Nominal \\
\hline $\begin{array}{l}\text { Ukuran Pemerintah } \\
\text { Daerah }\left(\mathrm{X}_{1}\right)\end{array}$ & $\begin{array}{l}\text { Ukuran pemerintah daerah } \\
\text { menunjukkan besarnya } \\
\text { pemerintahan daerah. }\end{array}$ & $\begin{array}{l}\text { SIZE = Ln Total Aset } \\
\text { cbcc }\end{array}$ & Rasio \\
\hline $\begin{array}{l}\text { Rasio Kemandirian } \\
\text { Daerah }\left(\mathrm{X}_{2}\right)\end{array}$ & $\begin{array}{l}\text { Rasio kemandirian daerah } \\
\text { dihitung dari besarnya } \\
\text { realisasi pendapatan asli } \\
\text { daerah dengan total } \\
\text { realisasi pendapatan yang } \\
\text { diterima. }\end{array}$ & $\mathrm{INDEP}=\frac{\text { Total PAD }}{\text { Total Pendapatan }}$ & Rasio \\
\hline $\begin{array}{l}\text { Rasio Pembiayaan } \\
\text { Hutang }\left(\mathrm{X}_{3}\right)\end{array}$ & $\begin{array}{lr}\text { Proporsi yang } \\
\text { menggambarkan besarnya } \\
\text { utang dari pihak eksternal } \\
\text { dibandingkan dengan } \\
\text { modal sendiri. }\end{array}$ & $\mathrm{LEV}=\frac{\text { Total Kewajiban }}{\text { Total Ekuitas }}$ & Rasio \\
\hline $\begin{array}{ll}\text { Belanja } & \text { Daerah } \\
\left(\mathrm{X}_{4}\right) & \end{array}$ & $\begin{array}{l}\text { Belanja daerah terkait } \\
\text { penganggaran yaitu } \\
\text { menunjukkan jumlah uang } \\
\text { yang telah dikeluarkan } \\
\text { selama satu tahun } \\
\text { anggaran. }\end{array}$ & 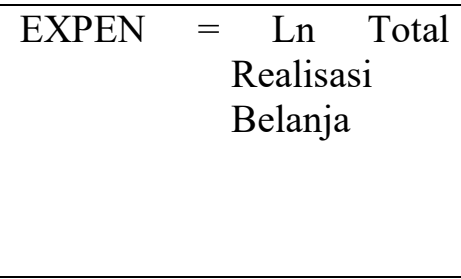 & Rasio \\
\hline
\end{tabular}




\section{Definisi Operasional Variabel}

\section{Metode Analisis Data}

Pengujian hipotesis dilakukan dengan analisis multivariat dengan menggunakan regresi logistik (logistic regression).

\section{Model Regresi Yang Digunakan}

Model regresi logistik yang digunakan untuk menguji hipotesis sebagai berikut:

$\mathbf{P}=\frac{1}{1+e^{-\left(b_{0}+b_{1} X_{1}+b_{2} X_{2}+b_{3} X_{3}+b_{4} X_{4}\right)}}$

Keterangan:

$\mathrm{P} \quad=$ Probabilitas pelaporan keuangan pemerintah daerah

$e \quad=$ Logaritma natural

$\mathrm{X}_{1}=$ Ukuran Pemerintah Daerah

$\mathrm{X}_{2}=$ Rasio Kemandirian Daerah

$\mathrm{X}_{3}=$ Rasio Pembiayaan Hutang

$\mathrm{X}_{4}=$ Belanja Daerah

$\mathrm{b}_{0} \quad=$ Konstanta regresi

$\mathrm{b}_{1}-\mathrm{b}_{4}=$ Koefisien regresi

\section{HASIL}

\section{Hasil Pengujian Hipotesis}

Berikut ini disajikan statistik deskriptif data pelaporan keuangan pemerintah daerah dari 80 sampel.

\section{Descriptive Statistics}

\begin{tabular}{|l|l|l|l|l|l|}
\hline & $\mathrm{N}$ & Minimum & Maximum & Mean & Std. Deviation \\
\hline $\mathrm{Y}$ & 80 & .00 & 1.00 & .7500 & .43574 \\
$\mathrm{X} 1$ & 80 & 12537624685.0 & 33441100000000 & 3065052870308.5 & 4267611760937.657 \\
& 80 & .02 & .00 & 625 & 70 \\
$\mathrm{X} 2$ & 80 & .00 & .50 & .1066 & .07491 \\
$\mathrm{X} 3$ & 80 & 318569000000. & 3753710000000. & 1082544937500.0 & 626772395699.5436 \\
$\mathrm{X} 4$ & 00 & 00 & 001 & 0 \\
& & & & \\
Valid N & & & & & \\
(listwise & 80 & & & & \\
) & & & & \\
\hline
\end{tabular}

Pengujian hipotesis dilakukan dengan menggunakan regresi logistik yang dilakukan secara bersama-sama untuk keempat variabel yaitu SIZE, INDEP, LEV, dan EXPEN dengan tingkat signifikansi 5\%. 
Perbandingan nilai aktual dan prediksi bisa dicapai dengan menggunakan beberapa pengukuran untuk mengukurkelayakan regresi, yaitu:

\section{Uji -2 log likehood}

Uji -2 log likehood digunakan untuk menilai model regresi logistik layak dipakai atau tidak. Tampilan output SPSS memberikan dua nilai -2 log likehood yaitu model yang hanya memasukkan konstanta dan model dengan konstanta serta variabel bebas ke dalam model regresi logistik. Hasil pengolahan data dapat dilihat pada tabel berikut :

\begin{tabular}{|c|c|c|}
\hline \multicolumn{3}{|c|}{$\begin{array}{l}\text { Pengujian -2 log likehood Step } 0 \\
\text { Iteration History }{ }^{\mathrm{a}, \mathrm{b}, \mathrm{c}}\end{array}$} \\
\hline Iteration & $\begin{array}{l}-2 \quad \log \\
\text { likelihood }\end{array}$ & $\begin{array}{l}\text { Coefficient } \\
\text { s } \\
\text { Constant }\end{array}$ \\
\hline $\begin{array}{ll}\text { Step } 0 & 1 \\
& 2 \\
& 3 \\
& 4\end{array}$ & $\begin{array}{l}90.122 \\
89.974 \\
89.974 \\
89.974\end{array}$ & $\begin{array}{l}1.000 \\
1.096 \\
1.099 \\
1.099\end{array}$ \\
\hline
\end{tabular}

\section{Pengujian -2 log likehood Step 1}

Model Summary

\begin{tabular}{|l|l|l|l|}
\hline Step & $\begin{array}{l}-2 \quad \text { Log } \\
\text { likelihood }\end{array}$ & $\begin{array}{l}\text { Cox \& Snell } \\
\text { R Square }\end{array}$ & $\begin{array}{l}\text { Nagelkerke } \\
\text { R Square }\end{array}$ \\
\hline 1 & $58.313^{\mathrm{a}}$ & .327 & .484 \\
\hline
\end{tabular}

Tabel diatas, menunjukkan hasil pengujian -2 log likehood. Pengujian ini terdiri dari dua tahap yaitu tahap 0 (step 0) dan tahap 1 (step1). Hasil yang baik apabila terdapat penurunan pada nilai -2 log likehood tahap 0 ke tahap 1. Berdasarkan tabel diatas dapat dilihat nilai -2 log likehood tahap 0 adalah 89.974 sedangkan nilai 2 log likehood pada tahap 1 adalah 58.313. Hal ini berarti terjadi penurunan nilai -2 log likehood. Jadi dapat ditarik kesimpulan bahwa model tersebut merupakan model regresi logistik yang baik dan penambahan variabel bebas ke dalam model memperbaiki model fit.

\section{Uji Nagelkerke R Square}

Uji Nagelkerke $R$ Squaredilakukan untuk menilai seberapa besar variasi dari variabel terikat (pelaporan keuangan pemda) dapat dijelaskan oleh variabel bebas (SIZE, INDEP, LEV, dan EXPEN). Hasil pengujian Nagelkerke R Square dapat dilihat pada tabel berikut : 
Pengujian Nagelkerke $R$ Square Model Summary

\begin{tabular}{llllll}
\hline Step & Cox \& & Snell & $\begin{array}{l}\text { R Nagelkerke } \\
\text { Square }\end{array}$ & R \\
Square & -2 Log likelihood & . \\
\hline 1 & $58.313^{\mathrm{a}}$ & .327 & & .484 \\
\hline
\end{tabular}

Berdasarkan tabel diatas nilai Nagelkerke $R$ Square adalah sebesar 0.484. Hal ini mengindikasikan bahwa variasi variabel dependent (pelaporan keuangan pemerintah daerah) dapat dijelaskan oleh variabel independen (SIZE, INDEP, LEV, dan EXPEN) sebesar $48.40 \%$ sedangkan sisanya $51.60 \%$ dijelaskan oleh variabel lain diluar model.

\section{Uji Hosmer and Lemeshow}

Uji Hosmer and Lemeshow dilakukan untuk menguji $\mathrm{H}_{0}$ bahwa data empiris cocokatau sesuai dengan model (tidak ada perbedaan model dengan data sehingga model dapat dikatakan fit). Jika nilai Hosmer and Lemeshow Test sama dengan atau kurang dari 0.05 , maka $\mathrm{H}_{0}$ ditolak berarti ada perbedaan signifikan antara model dengan nilai observasinya sehingga model tidak dapat memprediksi nilai observasinya, sebaliknya jika nilai Hosmer and Lemeshow Test lebih besar dari 0.05 maka $\mathrm{H}_{0}$ diterima yang berarti model mampu memprediksi nilai observasinya atau dapat dikatakan model dapat diterima karena sesuai dengan data observasinya.

\section{Pengujian Hosmer and Lemeshow}

\section{Hosmer and Lemeshow Test}

\begin{tabular}{|l|l|l|l|}
\hline Step & Chi-square & df & Sig. \\
\hline 1 & 8.205 & 8 & .414 \\
\hline
\end{tabular}

Berdasarkan tabel diatas, maka telah diperoleh nilai signifikansi Statistic Hosmer and Lemeshow's Goodness of Fit Test sebesar 0.414 yang nilainya diatas 0.05 . Hal ini berarti bahwa model mampu memprediksi nilai observasinya atau model dapat diterima karena sesuai dengan data observasinya.

\section{Uji Regresi Logistik Secara Parsial}

Regresi logistik secara parsial dengan melihat table variables in the equation. Pengujian hipotesis dengan menggunakan regresi logistik dilakukan dengan memasukkan seluruh variable SIZE, INDEP, LEV, dan EXPEN dan pelaporan keuangan pemda. Pengujian ini dilakukan dengan menggunakan metode enter dengan tingkat signifikansi sebesar 5\%. Dasar pengambilan keputusannya adalah apabila nilai signifikansi $>0.05$ maka $\mathrm{H}_{0}$ diterima sedangkan jika nilai signifikansi $<0.05$ maka $\mathrm{H}_{0}$ ditolak. Hasil pengujian tersebut dapat dilihat pada tabel berikut : 


\begin{tabular}{|c|c|c|c|c|c|c|}
\hline & B & S.E. & Wald & $\mathrm{df}$ & Sig. & $\begin{array}{l}\text { Odds Ratio } \\
\operatorname{Exp}(\mathrm{B})\end{array}$ \\
\hline Step X1 & .000 & .000 & 10.305 & 1 & .00 & 1.000 \\
\hline $\mathrm{X} 2$ & 45.526 & 13.530 & 11.322 & 1 & $\begin{array}{l}.00 \\
1\end{array}$ & $\begin{array}{l}59086421905435340000 \\
.000\end{array}$ \\
\hline X3 & -189.555 & 59.021 & 10.315 & 1 & .00 & .000 \\
\hline X4 & .000 & .000 & 2.730 & 1 & $\begin{array}{l}.09 \\
9\end{array}$ & 1.000 \\
\hline Constant & -1.176 & .973 & 1.461 & 1 & .22 & .308 \\
\hline
\end{tabular}

Berdasarkan hasil analisis regresi logistik, dari empat variabel independen dalam penelitian terdapat tiga variabel yang memperlihatkan pengaruh signifikan terhadap pelaporan keuangan pemerintah daerah yaitu $\mathrm{X}_{1}$ (Ukuran Pemda), $\mathrm{X}_{2}$ (Rasio Kemandirian Daerah) dan $\mathrm{X}_{3}$ (Rasio Pembiayaan Hutang). Sementara itu $\mathrm{X}_{4}$ (Belanja Daerah) berpengaruh tidak signifikan terhadap pelaporan keuangan pemerintah daerah. Secara ringkas, hasil pengujian hipotesis menggunakan analsis regresi logistik disajikan pada tabel berikut :

Ringkasan Hasil Pengujian Hipotesis Pelaporan Keuangan Pemerintah Daerah No Variabel Siginifikasi Kesimpulan Uji Hasil Uji Hipotesis Statistik

\begin{tabular}{lllll}
\hline 1 & SIZE $\left(\mathrm{X}_{1}\right)$ & .001 & $\mathrm{H}_{0}:$ Ditolak & Berpengaruh signifikan \\
\hline 2 & INDEP $\left(\mathrm{X}_{2}\right)$ & .001 & $\mathrm{H}_{0}:$ Ditolak & Berpengaruh signifikan \\
\hline 3 & LEV $\left(\mathrm{X}_{3}\right)$ & .001 & $\mathrm{H}_{0}:$ Ditolak & Berpengaruh signifikan \\
\hline 4 & EXPEN $\left(\mathrm{X}_{4}\right)$ & .099 & $\mathrm{H}_{0}:$ Diterima & $\begin{array}{l}\text { Berpengaruh } \\
\text { signifikan }\end{array}$ \\
\hline
\end{tabular}

Model regresi logistik yang digunakan sebagai berikut:

$\mathbf{P}=\frac{1}{1+e^{-\left(-1.176+0.000 X_{1}+45.526 X_{2}-189.555 X_{3}+0.000 X_{4}\right)}}$

Keterangan:

$\mathrm{P} \quad=$ Probabilitas pelaporan keuangan pemerintah daerah

e $\quad=$ Logaritma natural

$\mathrm{X}_{1} \quad=$ Ukuran Pemerintah Daerah

$\mathrm{X}_{2} \quad=$ Rasio Kemandirian Daerah

$\mathrm{X}_{3} \quad=$ Rasio Pembiayaan Hutang

$\mathrm{X}_{4} \quad=$ Belanja Daerah 
$\mathrm{b}_{0} \quad=$ Konstanta regresi

$\mathrm{b}_{1}-\mathrm{b}_{4}=$ Koefisien regresi

\section{Uji Regresi Logistik Secara Simultan (Omnibus Test of Model Coefficient)}

Pengujian secara simultan dalam regresi logistic disebut Omnibus Test of Model Coefficient. Omnibus Test of Model Coefficient bertujuan untuk melihat apakah keempat variable independen (SIZE, INDEP, LEV, dan EXPEN) secara bersama-sama berpengaruh terhadap pelaporan keuangan pemerintah daerah. Dasar pengambilan keputusannya adalah jika nilai signifikansi lebih besar dari alpha (0.05) maka $\mathrm{H}_{0}$ diterima sedangkan jika nilai signifikansi lebih kecil dari alpha (0.05) maka $\mathrm{H}_{0}$ ditolak. Hasil Omnibus Test of Model Coefficient dapat dilihat pada table berikut :

\section{Pengujian Regresi Logistik secara Simultan (bersama-sama)} Omnibus Tests of Model Coefficients

\begin{tabular}{|ll|l|l|l|}
\hline & & Chi-square & df & Sig. \\
\hline Step 1 & Step & 31.661 & 4 & .000 \\
& Block & 31.661 & 4 & .000 \\
& Model & 31.661 & 4 & .000 \\
\hline
\end{tabular}

Dari tabel diatas terlihat bahwa nilai signifikansi adalah sebesar 0.000. Angka $0.000<0.05$, maka dapat diambil keputusan bahwa $\mathrm{H}_{0}$ ditolak dan Ha diterima, artinya bahwa keempat variabel (SIZE, INDEP, LEV, dan EXPEN) secara simultan atau bersama-sama berpengaruh secara signifikan terhadap pelaporan keuangan pemerintah daerah.

\section{KESIMPULAN DAN SARAN Kesimpulan}

1. Secara simultan hasil pengujian hipotesis ukuran pemda, rasio kemandirian daerah, rasio pembiayaan hutang, dan belanja daerah secara bersama-sama berpengaruh signifikan terhadap pelaporan keuangan pemerintah daerah.

2. Secara parsial hasil pengujian hipotesis ukuran pemda berpengaruh signifikan terhadap pelaporan keuangan pemda. Maka, hipotesis penelitian ini diterima. Hasil ini sejalan dengan penelitian yang dilakukan oleh Serrano dkk (2008) dan Yurisca (2011) yang menunjukkan bahwa ukuran pemdaberpengaruh signifikan terhadap pelaporan keuangan pemda, tetapi temuan ini tidak konsisten dengan hasil penelitian yang dilakukan oleh Laswad dkk (2005).

3. Rasio kemandirian daerah berpengaruh signifikan terhadap pelaporan keuangan pemerintah daerah secara parsial. Maka, hipotesis penelitian ini diterima. Hasil ini sejalan dengan penelitian yang dilakukan oleh Laswad dkk (2005) dan Yurisca (2011) yang menunjukkan bahwa rasio kemandirian daerah berpengaruh signifikan terhadap pelaporan keuangan pemda. 
4. Rasio pembiayaan hutangberpengaruh terhadap pelaporan keuangan pemda sehingga hipotesis penelitian diterima secara parsial. Hasil ini sejalan dengan penelitian yang dilakukan oleh Laswad dkk (2005) dan Styles \& Tennyson (2007) yang menunjukkan bahwa rasio pembiayaan hutang berpengaruh signifikan terhadap pelaporan keuangan pemda, tetapi temuan ini tidak konsisten dengan hasil penelitian yang dilakukan oleh Yurisca (2011).

5. Belanja daerah berpengaruh tidak signifikan terhadap pelaporan keuangan pemda secara parsial. Sehingga hipotesis penelitian ini ditolak. Hasil penelitian ini sejalan dengan penelitian yang dilakukan oleh Rora (2010) yang menunjukkan bahwa belanja daerah berpengaruh tidak signifikan terhadap pelaporan keuangan pemda.

\section{Saran}

1. Penelitian selanjutnya diharapkan menggunakan beberapa tahun pengamatan untuk melihat bagaimana pengaruhnya untuk beberapa tahun.

2. Pada penelitian selanjutnya sebaiknya menambah sampel pemerintah daerah lainnya di Indonesia sehingga cakupan penelitian lebih luas lagi.

3. Pada penelitian ini variabel belanja daerah berpengaruh tidak signifikan terhadap pelaporan keuangan karena belanja daerah bersifat homogen. Penelitian selanjutnya dapat menambahkan variabel-variabel penelitian seperti kompetisi politik masing-masing daerah, belanja modal, dan press visibility.

\section{DAFTAR PUSTAKA}

Badan Pemeriksa Keuangan. 2015. Pokok-pokok ikhtisar hasil pemerintahan badan pemeriksa keuangan semester I Tahun 2015.

Gore, A.K. 2004.The Effects of GAAP Regulation and Bond Market Interactions on Local Government Disclosure.Journal of Accounting and Public Policy. Volume 23, Pages 23-52.

Kieso, Weygandt, Warfield. 2007. Intermediate Accounting, Twelfth Edition. Erlangga, Jakarta.

Laswad, F., Fisher, R., Oyelere, P. 2005. Determinants of Voluntary Internet Financial Reporting by Local Government Authorities. Journal of Accounting and Public Policy, 24, 101-121.

Peraturan Menteri Dalam Negeri No. 13 Tahun 2006 tentang Pedoman Pengelolaan Keuangan Daerah.

Peraturan Pemerintah Republik Indonesia No. 24 Tahun 2005 Tentang Standar Akuntansi Pemerintahan.

Peraturan Pemerintah Republik Indonesia No. 58 Tahun 2005 Tentang Pengelolaan Keuangan Daerah.

Peraturan Pemerintah Republik Indonesia No. 56 Tahun 2005 Tentang Sistem Informasi Keuangan Daerah. 
Peraturan Pemerintah Republik Indonesia No. 65 Tahun 2010 Tentang Sistem Informasi Keuangan Daerah.

Rora, Puspita Sari. 2010. Analisis Pengaruh Kinerja dan Karakteristik Pemda Terhadap Tingkat Pengungkapan dan Kualitas Informasi dalam Website Pemda.Simposium Nasional Akuntansi XV. Banjarmasin.

Serrano-Cinca, Carlos, Mar Rueda-Tomas, Pillar Portillo-Tarragona. 2008. Factors Influencing E-Disclosure in Local Public Administrations. Working Paper No.2008-03, Faculted de Ciencias Economicas y Espresariales, Universidad de Zaragoza.

Styles, Alan K; Mack Tennyson. 2007. The Accessibility of Financial Reporting U.S. Manucipalities on The Internet. Journal of Public Budgeting, Accounting \& Financial Management, 19 (1), 56-92.

Undang-Undang No. 32 Tahun 2004 Tentang Pemerintah Daerah.

Undang-Undang No. 33 Tahun 2004 Tentang Perimbangan Keuangan Antara Pemerintah Pusat dan Pemerintah Daerah.

Undang-Undang No. 14 Tahun 2008 Tentang Keterbukaan Informasi Keuangan.

Yurisca. 2011. Analisis Faktor-Faktor Yang Mempengaruhi Pelaporan Keuangan di Internet Secara Sukarela Oleh Pemerintah Daerah. Jurnal Manajemen, Akuntansi, Sistem Informasi UNDIP. 